\title{
Response of Sesame (Sesamum indicum L.) to various levels of Nitrogen and Phosphorus in agro-climatic condition of Peshawar
}

\author{
Muhammad Ibrahim*,Yousaf Jamal, Abdul Basir, Muhammad Adnan, \\ Inayat-ur-Rahman, Irshad Ali khan and Attaullah \\ Department of Agriculture University of Swabi Khyber Pakhtunkhwa-Pakistan \\ *Corresponding author's email: ibrahim@uoswabi.edu.pk
}

Citation

Muhammad Ibrahim, Yousaf Jamal, Abdul Basir, Muhammad Adnan, Inayat-ur-Rahman, Irshad Ali khan and Attaullah. Response of Sesame (Sesamum indicum 1.) to various levels of Nitrogen and Phosphorus in agro-climatic condition of Peshawar. Pure and Applied Biology. Vol. 5, Issue 1, 2016, pp121-126.

http://dx.doi.org/10.19045/bspab.2016.50016

\begin{tabular}{llll}
\hline \hline Received: 15/09/2015 & Revised: 04/12/2015 & Accepted: 29/12/2015 & Online First: 01/02/2016 \\
\hline
\end{tabular}

\section{Abstract}

Nitrogen is a structural component of chlorophyll and protein therefore adequate supply of nitrogen is beneficial for both carbohydrates and protein metabolism as it promotes cell division and cell enlargement, resulting in more leaf area and thus ensuring good seed and dry matter yield. The experiment entitled effect of nitrogen and phosphorus on yield and yield components of sesame were conducted at New Developmental Farm of the University of Agriculture Peshawar during kharif ( June 2013). Randomized complete block design (RCBD) having four replications were used. Nitrogen and phosphorus levels $\left(0,30,60,90 \mathrm{~kg} \mathrm{ha}^{-1}\right)$ each were applied in the form of $\mathrm{P}_{2} \mathrm{O}_{5}$ from DAP and urea respectively. The whole of phosphorus was applied during seed bed preparation and nitrogen in two splits, half at sowing and half after $80 \%$ emergence. The seed rate $4 \mathrm{~kg} \mathrm{ha}^{-1}$ of sesame (ocal black) was planted on $28^{\text {th }}$ June 2013. Total of 3 irrigations were applied, and other cultural practices were kept uniform for all the treatments. Highest number of pods plant ${ }^{-1}(67)$, number of seeds pods ${ }^{-1}(54)$, grain yield (520 $\mathrm{kg}$ ), biological yield $(2539 \mathrm{~kg})$, thousand seeds weight $(3.91 \mathrm{~g})$ and harvest index $(24 \%)$ were recorded when higher dose of N i.e. $90 \mathrm{~kg} \mathrm{ha}^{-1}$ were used. Similarly enhanced lowest number of pods plant ${ }^{-1}(55)$, number of seeds pods ${ }^{-1}(50)$, grain yield $(442 \mathrm{~kg})$, biological yield $(1570 \mathrm{~kg})$, thousand seed weight $(2.94 \mathrm{~g})$, and harvest index $(20 \%)$ were recorded in control plots. Application of phosphorous has significantly affected seeds $\operatorname{pod}^{-1}$, and biological yield. Whereas $90 \mathrm{~kg} \mathrm{P} \mathrm{ha}^{-1}$ increased plant tallness, pods plant ${ }^{-1}$, grains yield, thousand seeds weight and harvest index $(\%)$. The interaction was non-significant for all studied parameters. Therefore, it was concluded from the results that using nitrogen @ of $90 \mathrm{~kg} \mathrm{ha}^{-1}$ with $90 \mathrm{~kg} \mathrm{P} \mathrm{ha}^{-1}$ have improved the yield and yield components of sesame. Thus the application of $90 \mathrm{~kg} \mathrm{~N} \mathrm{ha}^{-1}$ with $90 \mathrm{~kg} \mathrm{Pha}^{-1}$ is recommended for general cultivation in agro-climatic condition of Peshawar valley.

Key words: Nitrogen; Phosphorus; Sesame; Seed pod; Yield components 


\section{Introduction}

Sesame (Sesamum indicum L.) belongs to family pedaliaceae is an annual, selfpollinated and indeterminate minor kharif oilseed crop. The stem is variously shaped, $60-120 \mathrm{~cm}$ tall and branched. The fruit is in the form of pods varies from 2.5 to $8.0 \mathrm{~cm}$ in length and 0.5 to $2.0 \mathrm{~cm}$ in diameter. Pods mature form bottom to top, allowing shattering of the lower ones by the time the uppermost pods are mature. Sesame seed are small and ovate with two distinct types, cream-colored and black. Cream-colored seeds are preferred. It is a short-day plant, normally flowering in 42-45 days [1] (Wikipedia, 2012). Sesame is an important edible oilseed crop. The seed contains all essential amino acids and fatty acids. It is a good source of vitamins (pantothenic acid and vitamin E) and minerals such as calcium (1450 mg $100 \mathrm{~g}^{-1}$ ) and phosphorous $(570 \mathrm{mg}$ $100 \mathrm{~g}^{-1}$ ) and the seed cake is also an important nutritious livestock feed [2].

In Pakistan, sesame was cultivated on an area of 90.7 ha thousand ha with an annual production of 41.0 tones with an average yield of $452 \mathrm{~kg} \mathrm{ha}^{-1}$ whereas in Khyber Pakhtunkhwa its average yield was $1000 \mathrm{~kg}$ ha $^{-1}$ during 2011-2012 [3]. Sesame was grown on over 7.8 million hectares of world's farms in 2010. The most productive Sesame seed farms in the world were in the European Union with an average yield of 5.5 metric tons $\mathrm{ha}^{-1}$ in 2010. Italy reported the best nationwide average yield of 7.2 metric tons $\mathrm{ha}^{-1}$ in 2010 . There is a huge yield gap and farm losses differences among major sesame seed producers due to knowledge gap, poor crop management practices and use of production technologies [1]. Soil and climatic conditions of Pakistan are highly favorable for sesame production yet its average yield is very low. Among the various factors of crop production, proper sowing dates, nitrogen and phosphorus levels and improved sesame cultivars play a key role in boosting its production.

Application of phosphorous at the rate of 50 $\mathrm{kg} \quad \mathrm{P}_{2} \mathrm{O}_{5} \mathrm{ha}^{-1}$ significantly enhanced seed yield, seed oil content and seed protein content increased pods plant ${ }^{-1}$ [4], whereas Olowe and Busari, [5] reported significantly increased growth, yield and yield attributes in Nigeria with the application of $13.2 \mathrm{~kg} \mathrm{P}$ $\mathrm{ha}^{-1}$ and increased number of leaves plant ${ }^{-1}$; number of seeds pod $^{-1}$ and seed yield $\mathrm{ha}^{-1}$ with the application of $26.4 \mathrm{~kg} \mathrm{P} \mathrm{ha}^{-1}$ were reported by Okpara et al. [6]. However, higher yields were obtained from the application of nitrogen $(\mathrm{N})$, phosphorus $(\mathrm{P})$ and adequate supply of nitrogen is beneficial for both carbohydrates and protein metabolism as it promote cell division and cell enlargement, resulting in, more leaf area and thus ensuring good seed and dry matter yield [7]. Survey reports have also shown that fertilizers are not applied to sesame even in major sesame growing areas of Nigeria [8].

Keeping in view the above constraints this experiment were conducted to find out the effect of nitrogen and phosphorus levels on the yield and yield components of sesame in agro-climatic condition of Peshawar.

\section{Materials and Methods}

The experiment entitled effect of nitrogen and phosphorus on yield and yield components of sesame were conducted at New Developmental Farm of the University of Agriculture Peshawar during kharif (June 2013). The experiment were laid out in randomized complete block design (RCBD) having four replications. The phosphorus $\mathrm{P}_{2} \mathrm{O}_{5}$ were applied from DAP and the remaining dose of nitrogen were applied from Urea in two splits half at sowing and half after $80 \%$ emergence. A plot size of $3 \times 3 \mathrm{~m}$ was used. Each plot was consisted of 6 rows, $50 \mathrm{~cm}$ apart and 3 $\mathrm{m}$ long. The seed rate $4 \mathrm{~kg} \mathrm{ha}^{-1}$ was used. The crop was sown at $28^{\text {th }}$ June and weeds 
were controlled manually. The field was ploughed 2 times first with cultivator and second time with rooter. Total number of irrigations was 3 for the crop throughout the whole growing season. All other agronomic practices were carried out uniformly for all the experimental units throughout the growing season.

\section{Results and discussion Pods plant ${ }^{-1}$ (Nos.)}

Data regarding pods plant $^{-1}$ presented in Table 1 showed that both nitrogen and phosphorous application had significantly affected pods plant $^{-1}$, whereas the interaction was found non-significant. Mean values of the data showed that increasing nitrogen rates had significantly increased pods plant $^{-}$ 1 . This result is in line with the findings of Ahmad et al. [7] and Malik et al. [2]. Application of $90 \mathrm{~kg} \mathrm{~N}^{-1}$ had resulted $22 \%$ higher pods plant $^{-1}$ over control treatment. Similarly, increasing phosphorous rate had increased pods plant ${ }^{-1}$ up to $60 \mathrm{~kg} \mathrm{P}$ $\mathrm{ha}^{-1}$, with no statistical differences when phosphorus was further increased up to 90 $\mathrm{kg} \mathrm{ha}{ }^{-1}$, and is supported with similar findings of Shehu et al. [8] and Haruna [9]. The results further indicated that highest pods plant ${ }^{-1}$ (63) was recorded at $90 \mathrm{~kg} \mathrm{P}^{-}$ ${ }^{1}$, followed by $60 \mathrm{~kg} \mathrm{P} \mathrm{ha}^{-1}$ pods plant ${ }^{-1}(61)$ plots as compared to lowest pods plant ${ }^{-1}$ (57) recorded at $0 \mathrm{~kg} \mathrm{P} \mathrm{ha}^{-1}$.

\section{Biological yield $\left(\mathrm{kg} \mathrm{ha}^{-1}\right)$}

Data regarding biological yield shown in Table 1. Indicated that highest biological yield (2539 $\mathrm{kg} \mathrm{ha}^{-1}$ ) was recorded at $90 \mathrm{~kg} \mathrm{~N}^{2}$ $\mathrm{ha}^{-1}$ compared to control plots $\left(1570 \mathrm{~kg} \mathrm{ha}^{-}\right.$ $\left.{ }^{1}\right)$. These significant affects might be associated with the increase in plant height, highest number of pods plant ${ }^{-1}$, number of leaves plant ${ }^{-1}$, and number of branches plan $^{-1}$ which increase total biomass of the plant and resulted in more biological yield. This show a $62 \%$ increase over control plots. The result is supported with the findings of Muhamman and Gungula. [10], El-
Nakhlawy and Shaheen [11]. No statistical differences were observed for biological yield in response to phosphorous application, and the interaction between phosphorous and nitrogen on biological yield of sesame supported with the findings of Rahman and Mahdi [12].

\section{Seeds pod ${ }^{-1}$ (Nos.)}

Statistical analysis of data showed that nitrogen application has significant effect on number of seeds pod $^{-1}$. Highest doses of nitrogen had highest number of seeds pod ${ }^{-1}$ while lowest doses (control) of nitrogen had the lowest number of number of seeds pod $^{-1}$. This might be due to more number of leaves and high nitrogen use efficiency and more interception of sun light and at the result more photos assimilates goes to reproductive parts of the plant which is seed of sesame. These results is in line with the findings of Malik et al. [2] reported that increase nitrogen application had increase the number of seed pod $^{-1}$, while phosphorus levels and interaction of nitrogen and phosphorus levels were found no significant on number of seed pod $^{-1}$.

\section{Grain yield ( $\mathrm{kg} \mathrm{ha}^{-1}$ )}

Grain yield positively responded to both nitrogen and phosphorus application. The highest grains yield $\left(520 \mathrm{~kg} \mathrm{ha}^{-1}\right)$ was recorded in $90 \mathrm{~kg} \mathrm{~N} \mathrm{ha}$ which was followed by $60 \mathrm{~kg} \mathrm{~N} \mathrm{ha}{ }^{-1}\left(512 \mathrm{~kg} \mathrm{ha}^{-1}\right)$, followed by $30 \mathrm{~kg} \mathrm{~N} \mathrm{ha}{ }^{-1}\left(494 \mathrm{~kg} \mathrm{ha}^{-1}\right)$. Significantly the lowest grain yield $(442 \mathrm{~kg}$ $\mathrm{ha}^{-1}$ ) was recorded in control plot. The result is supported with the findings of Ahmad et al. [7] and Malik et al [2]. The highest grains yield $\left(516 \mathrm{~kg} \mathrm{ha}^{-1}\right)$ was recorded in 90 $\mathrm{kg} \mathrm{P} \mathrm{ha}{ }^{-1}$ which was followed by $60 \mathrm{~kg} \mathrm{P} \mathrm{ha}^{-}$ 1 (509 kg ha ${ }^{-1}$ ), followed by $30 \mathrm{~kg} \mathrm{P} \mathrm{ha}{ }^{-1}$ $\left(497 \mathrm{~kg} \mathrm{ha}^{-1}\right)$. Significantly the lowest grain yield (446 kg ha-1) was recorded in control plot. The result is supported with the findings of Shehu et al. [8] and Haruna [9] who reported that increasing phosphorus levels of application significantly increase 
grain yield. The interactive effect of Phosphorus and Nitrogen on grains yield was found non-significant.

\section{Thousand seeds weight $(\mathrm{g})$}

Nitrogen application had significant effect on thousand seeds weight. Highest doses of nitrogen had highest thousand seeds weight while lowest doses (control) of nitrogen had the lowest thousand seeds weight the result is supported with the findings of Malik et al. [2] who reported the highest thousand seeds weight at $\left(80 \mathrm{~kg} \mathrm{~N} \mathrm{ha}^{-1}\right)$. These results might be associated with more number of leaves and secondary branches and trapping of more sun light that enhanced rate of photosynthesis and resulted much dry matter production assimilate in fruit (seed) of the plant at reproductive stage. Similarly phosphorus application had significant effect on thousand seeds weight. Highest doses of phosphorus had highest thousand seeds weight while lowest doses (control) of phosphorus had the lowest thousand seeds weight the result is supported with the findings of Mian et al. [13] conducted a field experiment to observe the crop performance under variable phosphorus levels and reported the highest thousand seeds weight at $\left.(90 \mathrm{~kg} \mathrm{P} \mathrm{ha})^{-1}\right)$. While the interaction of phosphorus and nitrogen levels have no significant effect on thousand seeds weight.

Table 1. Pods plant ${ }^{-1}$, biological yield and seeds pod $^{-1}$ of sesame as affected by different levels of nitrogen and phosphorus

\begin{tabular}{|c|c|c|c|}
\hline Treatments & Pods plant $^{-1}$ & Biological yield (kg) & Seeds pod ${ }^{-1}$ \\
\hline \multicolumn{4}{|c|}{ Nitrogen $\left(\mathrm{kg} \mathrm{N} \mathrm{ha}^{-1}\right)$} \\
\hline 0 & $55 \mathrm{c}$ & $1570 \mathrm{c}$ & $50 \mathrm{c}$ \\
\hline 30 & $58 \mathrm{~b}$ & $2182 \mathrm{~b}$ & $51 b$ \\
\hline 60 & $61 b$ & $2407 \mathrm{ab}$ & $52 b$ \\
\hline 90 & $67 \mathrm{a}$ & $2539 a$ & $54 \mathrm{a}$ \\
\hline $\mathrm{LSD}_{0.05}$ & 3 & 320 & 2 \\
\hline \multicolumn{4}{|c|}{ Phosphorus $\left(\mathrm{kg} \mathrm{P} \mathrm{ha}^{-1}\right)$} \\
\hline 0 & $57 \mathrm{c}$ & 2118 & 52 \\
\hline 30 & $59 \mathrm{bc}$ & 2229 & 51 \\
\hline 60 & $61 \mathrm{ab}$ & 2086 & 53 \\
\hline 90 & $63 \mathrm{a}$ & 2265 & 51 \\
\hline $\mathrm{LSD}_{0.05}$ & 3 & $\mathrm{NS}$ & $\mathrm{NS}$ \\
\hline $\mathrm{N} \times \mathrm{P}$ interaction & NS & NS & NS \\
\hline
\end{tabular}

\section{Harvest index (\%)}

Data regarding harvest index are shown in Table 2. The maximum harvest index (24\%) was recorded in $90 \mathrm{~kg} \mathrm{~N} \mathrm{ha-1}$ which was followed by $60 \mathrm{~kg} \mathrm{~N} \mathrm{ha}^{-1}(23 \%)$. Significantly the minimum harvest index (20\%) was recorded in control plot. The maximum harvest index $(25 \%)$ was recorded in $90 \mathrm{~kg} \mathrm{P} \mathrm{ha}{ }^{-1}$ which was followed by $60 \mathrm{~kg}$ $\mathrm{P} \mathrm{ha}^{-1}(23 \%)$. Significantly the minimum harvest index (20\%) was recorded in control plot. These results were also supported by Mian et al. [13], Shehu et al. [8] and Haruna [9] who reported that application of nitrogen and phosphorus significantly affected grain yield. As harvest index is correlated with grain yield, therefore increase in grain yield increase harvest index.

The interactive effect of phosphorus and nitrogen on harvest index was found nonsignificant. 
Table 2. Grain yield, thousand seed weight and harvest index (\%) of sesame as affected by different levels of nitrogen and phosphorus

\begin{tabular}{|c|c|c|c|}
\hline Treatments & $\begin{array}{r}\text { Grain yield } \\
(\mathrm{kg})\end{array}$ & $\begin{array}{r}\text { Thousand seeds } \\
\text { weight (gm) } \\
\end{array}$ & $\begin{array}{r}\text { Harvest index } \\
(\%) \\
\end{array}$ \\
\hline \multicolumn{4}{|c|}{ Nitrogen $\left(\mathrm{kg} \mathrm{N} \mathrm{ha}^{-1}\right)$} \\
\hline 0 & $442 b$ & $2.94 d$ & $20 \mathrm{c}$ \\
\hline 30 & $494 a$ & $3.16 \mathrm{c}$ & $22 b c$ \\
\hline 60 & $512 \mathrm{a}$ & $3.36 b$ & $23 a b$ \\
\hline 90 & $520 \mathrm{a}$ & $3.91 \mathrm{a}$ & $24 \mathrm{a}$ \\
\hline $\mathrm{LSD}_{0.05}$ & 28 & 0.17 & 2 \\
\hline \multicolumn{4}{|c|}{ Phosphorus $\left(\mathrm{kg} \mathrm{P} \mathrm{ha}^{-1}\right)$} \\
\hline 0 & $446 b$ & $3.19 \mathrm{c}$ & $20 b$ \\
\hline 30 & $497 \mathrm{a}$ & $3.23 \mathrm{bc}$ & $21 b$ \\
\hline 60 & $509 a$ & $3.36 \mathrm{~b}$ & $23 \mathrm{a}$ \\
\hline 90 & $516 a$ & $3.61 \mathrm{a}$ & $25 \mathrm{a}$ \\
\hline $\mathrm{LSD}_{0.05}$ & 28 & 0.17 & 2 \\
\hline $\mathrm{N} \times \mathrm{P}$ interaction & NS & NS & NS \\
\hline
\end{tabular}

NS = Non-significant.

Means followed by different letter ( $\mathrm{s}$ ) in each category are significantly different from each other using LSD test at $\mathrm{P} \leq 0.05$ using.

\section{Conclusion}

It was concluded from the results that application of nitrogen @ 90 kg ha ${ }^{-1}$ had significantly improved the yield and yield components, whereas phonological observation were delayed with increased nitrogen application. The phosphorus effects were restricted to influence plant height, number of pods ${ }^{-1}$, grain yield; thousand seed weight, harvest index, and have no effects on days to emergence, emergence $\mathrm{m}^{-2}$, days to flowering, days to maturity, plants $\mathrm{ha}^{-1}$, seeds pod $^{-1}$, and biological yield.

Thus it was recommended that nitrogen @ $90 \mathrm{~kg} \mathrm{ha}^{-1}$ with phosphorus @ $90 \mathrm{~kg} \mathrm{ha}^{-1}$ would result in highest yield and yield components of sesame and is recommended for the farmers of Peshawar valley.

\section{Authors' contributions}

Conceived and designed the experiment: $\mathrm{M}$ Ibrahim \& Y Jamal, Analyzed the data: A Basir \& M Adnan, Provided the materials and analysis tools for experiment: IA khan,
Performed the experiment: Attaullah, Wrote the paper: I Rahman \& M Ibrahim.

\section{References}

1. Wikipedia

2012. http://en.wikipedia.org/wiki/Sesame.

retrieved on (25 October 2013, at 18:58).

2. Malik MA, Saleem MF, Cheema MA \& Ahmed S (2003). Influence of different nitrogen levels on productivity of sesame (Sesamum indicum L.) under varying planting patterns. Int J Agri Biol 5(4): 490-492.

3. MINFA (2012). Ministry of Food and Agriculture. Agricultural Statistics of Pakistan. Govt. of Pak, Eco. Wing, Islamabad.

4. Haggai PT (2004). Effects nitrogen and phosphorus application on yield attributes and seed yield of sesame (Sesamum indicum L.) in Nigeria. Proceedings of $38^{\text {th }}$ Annual Conference of the Agricultural Society of Nigeria 
(ANS) Lafiya, Nasarawa State, Nigeria. 150-157.

5. Olowe VIO \& Busari LD (2000). Response of sesame (Sesamum indicum L.) to nitrogen and phosphorus application in Nigeria. Tropical Oilseed J 30-37.

6. Okpara DA, Muoneke CO \& Ojikpong TA (2007). Effects of nitrogen and phosphorus fertilizer rates on the growth and yield of sesame (Sesamum indicum L.). Nigerian Agric J 38: 01-11.

7. Ahmad A, Akhtar M, Hussain A, Ehsanullah \& Musaddique M (2001). Genotypic response of sesame to nitrogen and phosphorus application. Pak J Agri Sci 38(2): 12-15.

8. Shehu EH, Kwari JW \& Sandabe MK (2010) Nitrogen, phosphorus and potassium nutrition of sesame (Sesamum indicum L.). New York Sci J 3(12): 2127.

9. Haruna M (2011). Growth and yield of sesame (Sesamum indicum L.) as affected by poultry manure, nitrogen and phosphorus at samaru, Nigeria. $J$ Animals \& Plant Sci 21(4): 653-659.

10. Muhamman MA \& Gungula DT (2008). Growth parameters of sesame (Sesamum indicum L.) as affected by nitrogen and phosphorous levels in Mubi. Nigeria. $J$ Sustainable Dev in Agri \& Env 3(2): 8086.

11. EI-Nakhlawy F \& Shaheen MA (2009). Response of seed yield, yield components and oil content of the sesame cultivar and nitrogen fertilizer rate diversity. JKAU: Met Env \& Arid Land Agri Sci 20(2): 21-31.

12. Rahman A \& Mahdi AEl (2008). Response of sesame (Sesamum indicum L.) to nitrogen and phosphorus fertilization in Northern Sudan. The $1^{\text {st }}$ International e-Conference on Agric Bio Sci 1: 62-63.

13. Mian MAK, Uddin MK, Islam MR, Sultana NA \& Kohinoor H (2011). Crop performance and estimation of the effective level of phosphorus in sesame (Sesamum indicum L.). Acad J Pl Sci 44(1): 01-05. 